\title{
Tumor necrosis factor-alpha (TNF- $\alpha$ ) promotes cell survival during spermatogenesis, and this effect can be blocked by infliximab, a TNF- $\alpha$ antagonist
}

\author{
Janne S Suominen, Yangyang Wang, Antti Kaipia ${ }^{1}$ and Jorma Toppari \\ Departments of Physiology and Pediatrics, University of Turku, Turku, Finland and ${ }^{1}$ Department of Surgery, University of Tampere, Tampere, Finland \\ (Correspondence should be addressed to J Toppari, Departments of Physiology and Pediatrics, Kiinamyllynkatu 1020520 Turku, Finland; \\ Email: jorma.toppari@utu.fi)
}

\begin{abstract}
Objective: Tumor necrosis factor-alpha (TNF- $\alpha$ ) has been shown to inhibit germ cell death in human seminiferous epithelium. In the present study, we wanted to explore the effects of TNF- $\alpha$ in the rat seminiferous epithelium and to study molecular mechanisms of germ cell apoptosis. Furthermore, the effects of infliximab were studied. Infliximab is a TNF- $\alpha$ antagonist used in autoimmune disorders, such as rheumatoid arthritis and Crohn's disease.

Methods: Rat seminiferous tubule segments were cultured in the presence and absence of TNF- $\alpha$, infliximab and SN50, a NF- $\mathrm{BB}$ inhibitor. TUNEL-staining and cleaved caspase-3 immunohistochemistry combined with squash preparations of rat seminiferous tubule segments were used to evaluate the number of apoptotic cells. Western blot analyses were performed on cultured seminiferous tubule segments for Bcl-2 family proteins (Bax, Bad, Bcl-w, Bcl-xL) and fas ligand.

Results: TNF- $\alpha$ promotes cell survival in the rat seminiferous epithelium, and this prosurvival effect can be blocked by infliximab, a TNF- $\alpha$ antagonist. Bcl-xL was found to be upregulated in mitochondrial membranes by TNF- $\alpha$, and this upregulation was inhibited by infliximab. Inhibition of NF-кB translocation to the nucleus prevented the prosurvival effect of TNF- $\alpha$ on seminiferous epithelium. Conclusions: The present study demonstrates that TNF- $\alpha$ promotes cell survival in the rat seminiferous epithelium, and this effect can be blocked by infliximab. This is the first study to show the effects of infliximab in the testis. The prosurvival effect of TNF- $\alpha$ might be at least partly mediated by modulating the expression and subcellular localization of Bcl-2 family proteins.
\end{abstract}

European Journal of Endocrinology 151 629-640

\section{Introduction}

Normal spermatogenesis includes apoptotic cell death of some of the developing germ cells. It has been estimated that up to $75 \%$ of the hypothetical sperm number is lost due to apoptosis in early spermatogenesis $(1,2)$. The reason for this cell loss in the testis is explained by maintaining an optimal ratio of Sertoli cells to germ cells. Sertoli cells are essential for germ cell maturation, and the number of maturing germ cells is limited by the number of Sertoli cells (3). Tumor necrosis factor-alpha (TNF- $\alpha$ ) belongs to the TNF- $\alpha$ superfamily of death ligands, which at present has 19 members and was first identified 20 years ago as a cytokine with antitumor effects in vitro and in vivo $(4,5)$. It causes inflammatory, antiviral and immunoregulatory effects, stimulates proliferation of normal cells, and exerts cytolytic and cytostatic action against tumor cells (6). The effects of TNF- $\alpha$ are mediated through two receptors, TNFR1 and TNFR2. TNFR1 contains the cytoplasmic death domain and belongs to the family of death receptors. Through the death domain, TNFR 1 activates the caspase cascade, leading to cell death. However, TNFR1 also mediates effects that promote cell survival by activation of transcription factors, such as NF-кB and AP-1, which can induce genes involved in the suppression of apoptosis. In mouse testis, bioactive TNF- $\alpha$ is mainly produced by the round spermatids (7), and TNFR1 is found in porcine and human Sertoli and Leydig cells (8-10). In human testis, TNF- $\alpha$ inhibits germ cell apoptosis and downregulates Fas ligand, another member of the TNF- $\alpha$ superfamily of death ligands (10). Infliximab is a chimeric monoclonal antibody to human TNF- $\alpha$ with potent anti-inflammatory effects, and it is in therapeutic use for rheumatoid arthritis (RA) and Crohn's disease (CD) (11-13). Infliximab antagonizes TNF- $\alpha$, and it has been shown to cause apoptosis of $\mathrm{T}$ lymphocytes in the gut mucosa (14). It is an effective and welltolerated therapy for the management of RA and CD, although there are concerns that the immunogenicity of the anti-TNF antibody may result in the formation of human antichimeric antibodies as well as lymphoproliferative disorders $(12,13)$. The Bcl-2 family 
of proteins is an important regulator of cell survival. It consists of proapoptotic (such as Bid, Bik, Bim, Bad, Bax, Bak and Bok) and antiapoptotic (such as Bcl-2, Bcl-w, Bcl-xL, A1 and Mcl1) proteins. Proapoptotic family members are divided into two groups, the BH3-only family (such as Bid, Bik, Bim and Bad), which are related by the conserved $\mathrm{BH}-3$ domain (Bcl-2 homology), and the Bax family (Bax, Bak and Bok). Both types of proapoptotic members are needed during the apoptotic process: the $\mathrm{BH}-3$-only proteins act as direct antagonists of prosurvival proteins, whereas Bax family proteins act further downstream, affecting mitochondrial integrity (15). In cellular stress, the Bcl-2 family members congregate at intracellular membranes, of which mitochondria are the best studied in respect of apoptosis machinery. In this study, we wanted to find out whether TNF- $\alpha$ has a prosurvival effect on rat seminiferous epithelium and whether the possible effect could be blocked by infliximab, a TNF- $\alpha$ antagonist. The aim was to evaluate the expression of Bcl-2 family proteins in the rat seminiferous epithelium in the presence of $\mathrm{TNF}-\alpha$ and infliximab.

\section{Materials and methods}

\section{Experimental animals}

Sprague-Dawley rats were housed in a constant temperature $\left(20^{\circ} \mathrm{C}\right)$ and light-dark cycle (lights on, 0600-2000 h) with free access to food and water. Rats in all experiments were killed by $\mathrm{CO}_{2}$ asphyxiation, and testes were removed for subsequent analysis. All animal experiments were approved by the Turku University Committee on Ethics of Animal Experimentation.

\section{Sequential microdissection of the seminiferous tubules, tissue culture and stimulation}

The testes were decapsulated on a Petri dish containing Ham's F12 Dulbecco's MEM (1:1 DMEM/F12; GIBCO BRL, Paisley, UK) supplemented with $0.1 \%$ BSA and gentamycin sulfate $(50 \mu \mathrm{g} / \mathrm{ml})$. By transilluminationassisted microdissection $(16,17)$, 5-mm-long segments of pooled stages VII-VIII and IX-XII and 1-mm-long segments of stage XII from the rat seminiferous epithelial cycle were dissected for the Western blotting analyses and apoptosis assays. In tissue cultures, for in situ $3^{\prime}$-end labeling (ISEL), we used human TNF- $\alpha$; for other experiments, we used mouse TNF- $\alpha$ (Roche Diagnostics $\mathrm{GmbH}$, Mannheim, Germany). Infliximab was used at $10 \mu \mathrm{g} / \mathrm{ml}$ concentration and was purchased from a pharmaceutic supplier (ScheringPlough, Kenilworth, NJ, USA). This concentration has been shown to be effective in inhibition of TNF- $\alpha$ mediated cell activation (18). The NF-кB inhibitor SN50 was used at $50 \mu \mathrm{g} / \mathrm{ml}$ concentration (Biomol,
Plymouth Meeting, PA, USA) (19). For all Western blotting and ISEL experiments, 1:1 DMEM/F12 was supplemented as mentioned above. For the experiment presented in Fig. 2, 1:1 DMEM/F12 was supplemented with $0.001 \%$ BSA and gentamycin sulfate $(50 \mu \mathrm{g} / \mathrm{ml})$. For the experiment presented in Fig. 3, 1:1 DMEM/F12 was supplemented with $0.01 \%$ BSA and gentamycin sulfate $(50 \mu \mathrm{g} / \mathrm{ml})$.

\section{Squash preparations}

Segments $1 \mathrm{~mm}$ long of rat seminiferous tubule from stage XII were incubated $6-24 \mathrm{~h}$ in $100 \mu \mathrm{l}$ Ham's F12 Dulbecco's MEM (1:1 DMEM/F12), supplemented, as described above, in a humidified atmosphere $(5 \%$ $\mathrm{CO}_{2}, 34^{\circ} \mathrm{C}$ ), in the presence or absence of the test chemicals, and then transferred in $15 \mu \mathrm{l}$ culture medium onto a microscope slide. The tubules were carefully squashed between microscope slides and cover slips by following the formation of cellular monolayer under phase-contrast microscopy. Next, the squash preparations were snap frozen in liquid nitrogen, and then the cover slips were removed. The slides were dipped briefly in ice-cold 96\% ethanol, fixed in $10 \%$ formalin for $10 \mathrm{~min}$ and transferred to PBS.

\section{In situ 3'-end labeling (ISEL), cleaved caspase- 3 immunohistochemistry and quantification of germ cells}

After fixation, the slides were washed twice in PBS for $5 \mathrm{~min}$, post-fixed in ethanol:acetic acid $(2: 1, \mathrm{v} / \mathrm{v})$, again washed in PBS and finally dehydrated in ascending ethanol series, air dried and stored at $-70^{\circ} \mathrm{C}$. ISEL was done as previously described (20) with modifications. Each incubation was performed in a humidified box. The squash preparations were rehydrated in ethanol solutions of descending concentrations. Samples were incubated for $10 \mathrm{~min}$ in $1 \times$ TdT buffer (Boehringer Mannheim, Mannheim, Germany) before 3'end-labeling. A volume of $10 \mu \mathrm{l}$ labeling mixture, containing $2 \mu \mathrm{l}$ fresh $5 \times \mathrm{TdT}$ (Boehringer Mannheim), $0.16 \mu \mathrm{l}$ terminal deoxynucleotidyl transferase (Boehringer Mannheim), $0.05 \mu \mathrm{l}$ Dig-11-ddUTP $(1 \mathrm{nmol} / \mu \mathrm{l}$, Boehringer Mannheim), $2 \mu \mathrm{l} 25 \mathrm{mM} \mathrm{CoCl}_{2}$ (Boehringer Mannheim), $0.09 \mu \mathrm{l} 5 \mathrm{mM}$ ddATP (Amersham Pharmacia Biotech, Piscataway, NJ, USA) and $5.7 \mu$ l water, was applied to each sample, and the incubation was performed at $37^{\circ} \mathrm{C}$ for $1 \mathrm{~h}$. After the slides had been washed three times for $10 \mathrm{~min}$ each in a Tris buffer $(150 \mathrm{mM} \mathrm{NaCl}$ and $100 \mathrm{mM}$ Tris- $\mathrm{HCl}, \mathrm{pH} 7.4$ ), about $20 \mu \mathrm{l}$ of the same buffer containing $2 \%(\mathrm{w} / \mathrm{v})$ of blocking reagent (Boehringer) were applied to each slide, and the samples were incubated at room temperature (RT) for $30 \mathrm{~min}$. A volume of $20 \mu \mathrm{l} 2 \%(\mathrm{w} / \mathrm{v})$ blocking buffer containing diluted (1/4000) antidigoxigenin alkaline phosphatase conjugate (anti-DIG-AP; Boehringer Mannheim) was 
applied to the samples, which were then incubated at RT for $2 \mathrm{~h}$. The slides were washed (three times for $10 \mathrm{~min}$ ) in the Tris buffer and then left for 5-10 min in alkaline phosphatase buffer $(100 \mathrm{mM}$ Tris $-\mathrm{HCl}, 100 \mathrm{mM} \mathrm{NaCl}$ and $\left.50 \mathrm{mM} \mathrm{MgCl}_{2}, \mathrm{pH} 9.5\right)$. A volume of $20 \mu \mathrm{l}$ substrate solution containing nitroblue tetrazolium salt (NBT) and 5-bromo-4-chloro-3-indolyl phosphate (BCIP) (Boehringer Mannheim) was diluted with $1 \mathrm{ml}$ alkaline phosphatase buffer, and then about $20 \mu \mathrm{l}$ of this solution were added to each sample at RT. After the color reaction was estimated to be fully developed, the slides were treated for at least $5 \mathrm{~min}$ in EDTA buffer (100 mM Tris-HCl and $1 \mathrm{mM}$ EDTA, pH 8.0) to stop the reaction. Preparations were mounted, and the number of apoptotic cells was calculated under a light microscope. For cleaved caspase-3 immunohistochemistry, the slides were treated with hydrogen peroxide $\left(\mathrm{H}_{2} \mathrm{O}_{2}\right)$ for $15 \mathrm{~min}$ after fixation and again washed twice in PBS for $5 \mathrm{~min}$. The cell membranes were permeabilized with $0.1 \%$ Triton-X in PBS for $15 \mathrm{~min}$ and rinsed briefly with PBS. The squash preparations were blocked with buffer containing 5\% normal goat serum (NGS), 1\% BSA and $0.1 \%$ Triton-X for 30 min. Cleaved caspase- 3 antibody was added to squash preparation in 1:40 dilution in buffer containing 1\% BSA and $0.1 \%$ Triton-X in PBS for $2 \mathrm{~h}$. The slides were washed (three times for $10 \mathrm{~min}$ ) in PBS, and antirabbit horseradish peroxidase (HRP)-linked secondary antibody was added in 1:200 dilution in 1\% BSA and $0.1 \%$ Triton-X in PBS for $1 \mathrm{~h}$ and washed three times for $10 \mathrm{~min}$ in PBS. Diaminobenzidine (DAB) staining was done according to the manufacturer's instructions (Zymed Laboratories, South San Francisco, CA, USA). Preparations were mounted, and the number of apoptotic cells was calculated in a blinded fashion under a light microscope.

\section{Protein extraction, subcellular fractionation and SDS-PAGE}

Seminiferous tubules for Western blotting analysis were lysed with syringe and needle in buffer A (1\% NP40, $0.5 \%$ sodium deoxycholate, $0.1 \%$ SDS, $1 \mathrm{mM}$ EDTA, $1 \mathrm{mM}$ EGTA, $1 \mathrm{mM}$ sodium orthovanadate and $20 \mathrm{mM}$ sodium fluoride in PBS, pH 7.4) supplemented with protease inhibitor cocktail (Sigma-Aldrich, St Louis, MO, USA) at $4^{\circ} \mathrm{C}$ for $30 \mathrm{~min}$. Cell lysates were centrifuged for $20 \mathrm{~min}$ at $15000 \boldsymbol{g}$, and the supernatants were removed to new tubes for concentration measurements. For preparation of cytosolic and mitochondrial fractions, seminiferous tubule segments were homogenized on ice with five strokes of a teflon pestle in a glass homogenizer (Cowie Technology, Middlesbrough, UK) in the presence of buffer $\mathrm{B}(0.3 \mathrm{M}$ sucrose, $5 \mathrm{mM}$ TES and $200 \mathrm{nM}$ EGTA in PBS, pH 7.4) supplemented with protease inhibitor cocktail (Sigma-Aldrich). The homogenates were centrifuged at $650 \boldsymbol{g}$ for $10 \mathrm{~min}$ at $4^{\circ} \mathrm{C}$ to remove cell debris. The supernatant was centrifuged at $10000 \mathrm{~g}$ for $15 \mathrm{~min}$ at $4^{\circ} \mathrm{C}$ to sediment the fraction containing mainly mitochondria. The mitochondria were washed in buffer B and pelleted. The cytosolic fraction was isolated by centrifuging the $10000 \boldsymbol{g}$ supernatant fraction at $100000 \boldsymbol{g}$ for $60 \mathrm{~min}$ at $4^{\circ} \mathrm{C}$. Protein concentrations were measured by BCA protein assay kit (Pierce, Rockford, IL, USA). The protein was mixed with sample buffer $(0.25 \mathrm{M}$ Tris-HCl, pH 6.8, 4\% SDS, 20\% glyserol, 1.1 M 2-mercaptoethanol and $2 \%$ bromophenol blue) and boiled for 5 min. The proteins were separated in a $8-13 \%$ SDSpolyacrylamide gel by the Mini Protean II System (Bio-Rad, Hercules, CA, USA). After electrophoresis, the protein was electrophoretically transferred onto a PVDF-membrane (Hybond-P; Amersham), according to the manufacturer's instructions.

\section{Antibodies for immunohistochemistry and Western blotting}

A rabbit monoclonal antibody against cleaved caspase-3 (Asp175) was purchased from Cell Signaling Technology (Beverly, MA, USA). A mouse monoclonal antibody against Fas ligand (clone G247-4), a mouse monoclonal antibody against cytochrome c (clone 7H8.2C12) and a rabbit polyclonal antibody against Bax (raised against residues 43-61 of mouse Bax) were purchased from BD Pharmingen (San Diego, CA, USA). A mouse monoclonal antibody against Bcl-xL (clone 2H12) and a rabbit polyclonal antibody against Bcl-w (raised against residues 16-29 of human Bclw) were purchased from Stressgen Biotechnologies (Victoria, Canada). A mouse monoclonal antibody against Ox-Phos complex IV (COX4, clone 20E89) was used to verify the purity of the cytosolic fraction from mitochondria; it was purchased from Molecular Probes (Eugene, OR, USA). A mouse monoclonal anti-actin antibody was purchased from ICN Biomedicals (Costa Mesa, CA, USA).

\section{Western blotting analysis}

The membrane was incubated in blocking buffer $(0.1 \%$ Tween-20 and 5\% nonfat milk powder in PBS or TBS for Bax, Bcl-w, Bcl-xL, Bad, actin and cytochrome c, or cleaved caspase- 3 and COX4 respectively) at RT for $1 \mathrm{~h}$. The primary antibody incubation was performed at $4{ }^{\circ} \mathrm{C}$ overnight in blocking buffer for cleaved caspase-3, COX4 and cytochrome $\mathrm{c}$ and in PBS-T (PBS containing $0.1 \%$ Tween-20) for Bax, Bcl-w, Bcl-xL Bad and actin. After washes (three times for $10 \mathrm{~min}$ ) in PBS-T/TBS-T, the membrane was incubated with HRP-linked secondary antibodies (Amersham) for $1 \mathrm{~h}$ at RT. After washes (three times for $10 \mathrm{~min}$ ) in PBS-T/TBS-T, the membrane was subjected to chemiluminiscent detection with the ECL Plus Kit (Amersham). The membrane was exposed to Fuji RX-100 film (Eastman Kodak, Rochester, NY, USA) for $15 \mathrm{~s}-15 \mathrm{~min}$. Stripping of the membrane was done according to the manufacturer's instructions and reprobed with another antibody. 


\section{Densitometric analysis of Western blotting results}

The X-ray films of Western blotting were first scanned by a UMAX scanner (Super Vista S-20; Binuscan, Mamaroneck, NY, USA) and a Photoperfect software package (Binuscan). The images were saved as TIFFtype files (*tif, Microsoft, Redmond, WA, USA, and Aldus Co., Seattle, WA, USA) and then quantified by Tina 2.0 densitometric analytic system (Raytest Isotopenmesgerate $\mathrm{GmbH}$, Straubenhardt, Germany), according to the manufacturer's instructions.

\section{Statistical analysis}

In Western blotting analyses, the densitometric values of the signals were first normalized against the values obtained from the antiactin control blotting. The values from different experiments were pooled for calculation of means and S.E.M. and for one-way ANOVA, and Dunnett's (in dose-response studies) and Tukey's (multiple comparisons) tests by SPSS 11.0 (SPSS Inc., Chicago, IL, USA). For quantification of ISEL and cleaved caspase-3 results, the experiments were repeated three times, and in each repeat the mean value was obtained from three to four parallel specimens. In the experiments presented in Figs 1 and 3, logarithmic transformation of the values was used to normalize the distribution in treatment groups. $P$ values less than 0.05 were considered statistically significant.

\section{Results}

\section{TNF- $\alpha$ promotes cell survival in dose- dependent manner, and this effect can be blocked with infliximab, a TNF- $\alpha$ antagonist}

Segments $1 \mathrm{~mm}$ long from stage XII of the rat seminiferous epithelial cycle were cultured for $24 \mathrm{~h}$ in the presence or absence of different concentrations of TNF- $\alpha$, with or without infliximab. Squash preparations were done from tubule segments to form a monolayer of tubular cells for in situ 3'-end labeling (ISEL) to evaluate the number of apoptotic cells in specimens. When compared with the control, the number of apoptotic cells was significantly lower in the presence of $10 \mathrm{ng} / \mathrm{ml}$ TNF- $\alpha$. Infliximab blocked this prosurvival effect of TNF- $\alpha$ (Fig. 1). The prosurvival effect of TNF- $\alpha$ was verified by immunohistochemistry with a cleaved caspase-3 antibody. Segments $1 \mathrm{~mm}$ long from stage XII of rat seminiferous epithelium were cultured for $8 \mathrm{~h}$ in the presence or absence of different concentrations of TNF- $\alpha$, with and without infliximab. Squash preparations were done from tubule segments for immunohistochemistry to evaluate the number of apoptotic cells in specimens. The apoptotic cells were identified as germ cells, mostly primary spermatocytes and spermatids, on the basis of staining pattern and morphology. When compared with the control, the number of apoptotic cells was significantly lower in the presence of 10 and $100 \mathrm{ng} / \mathrm{ml}$ TNF-alpha after 8-h incubation. Infliximab again blocked this prosurvival effect of TNF- $\alpha$ (Fig. 2). Prosurvival $\mathrm{ED}_{50}$ for TNF- $\alpha$ appears to be $1-10 \mathrm{ng} / \mathrm{ml}$ in our seminiferous tubule culture.

\section{NF-אB translocation inhibitor SN50 has proapoptotic effect on rat seminiferous epithelium and abolishes the prosurvival effect of TNF- $\alpha$}

Segments $1 \mathrm{~mm}$ long from stage XII of the rat seminiferous epithelial cycle were cultured for $16 \mathrm{~h}$ in the presence and absence of $10 \mathrm{ng} / \mathrm{ml} \mathrm{TNF-} \alpha$ with and without SN50, a NF-kB translocation inhibitor. Squash preparations were done from tubule segments for immunohistochemistry with cleaved caspase- 3 antibody to evaluate the number of apoptotic cells in specimens. The number of apoptotic cells in fresh control was low, as expected. After 16-h incubation, the number of apoptotic cells was significantly lower in the presence of TNF- $\alpha$ compared with control. The number of apoptotic cells in the tubules treated with both TNF- $\alpha$ and SN50 increased sixfold compared with TNF- $\alpha$-treated tubules. SN50 had a proapoptotic effect on seminiferous epithelium, as the number of apoptotic cells in SN50-treated cells was 2.5-fold higher than in control (Fig. 3).

The expression of Bcl-w, Bcl-xL, Bad or Bax is not affected by TNF- $\alpha$ or infliximab analyzed in total tubule homogenates Segments $5 \mathrm{~mm}$ long from pooled stages VII-VIII and IX-XII of the rat seminiferous epithelial cycle were cultured for $21 \mathrm{~h}$ in the presence and absence of different concentrations of TNF- $\alpha$, with and without infliximab. The expression of Bcl-w, Bcl-xL, Bad or Bax was not affected by TNF- $\alpha$ or infliximab analyzed in total tubule homogenates (Fig. 4; data shown from pooled stages IX-XII).

TNF- $\alpha$ stimulation leads to an increased amount of Bcl-xL in mitochondria, and this increase can be blocked by infliximab Segments $5 \mathrm{~mm}$ long from pooled stages IX-XII of the rat seminiferous epithelial cycle were cultured for $6 \mathrm{~h}$ in the presence and absence of $10 \mathrm{ng} / \mathrm{ml}$ TNF- $\alpha$, with and without infliximab. The protein was extracted from mitochondrial and cytosolic fractions. During 6-h incubation, the amount of Bcl-xL decreased in the mitochondrial fraction compared with the 0-h control (Fig. 5). Stimulation by TNF- $\alpha$ increased the amount of Bcl-xL in the mitochondrial fraction. Infliximab blocked this increase. No changes were observed in 
A
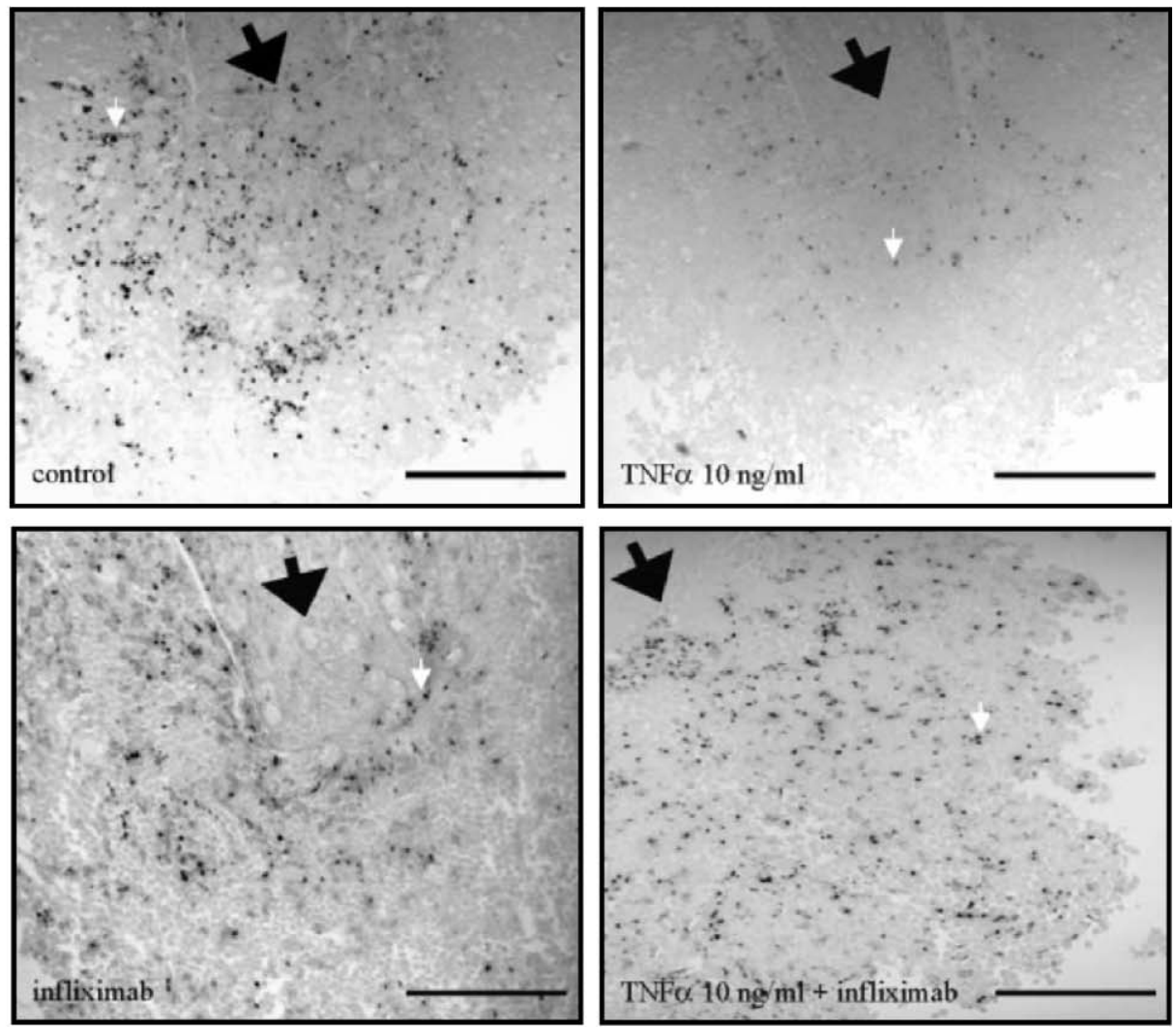

B

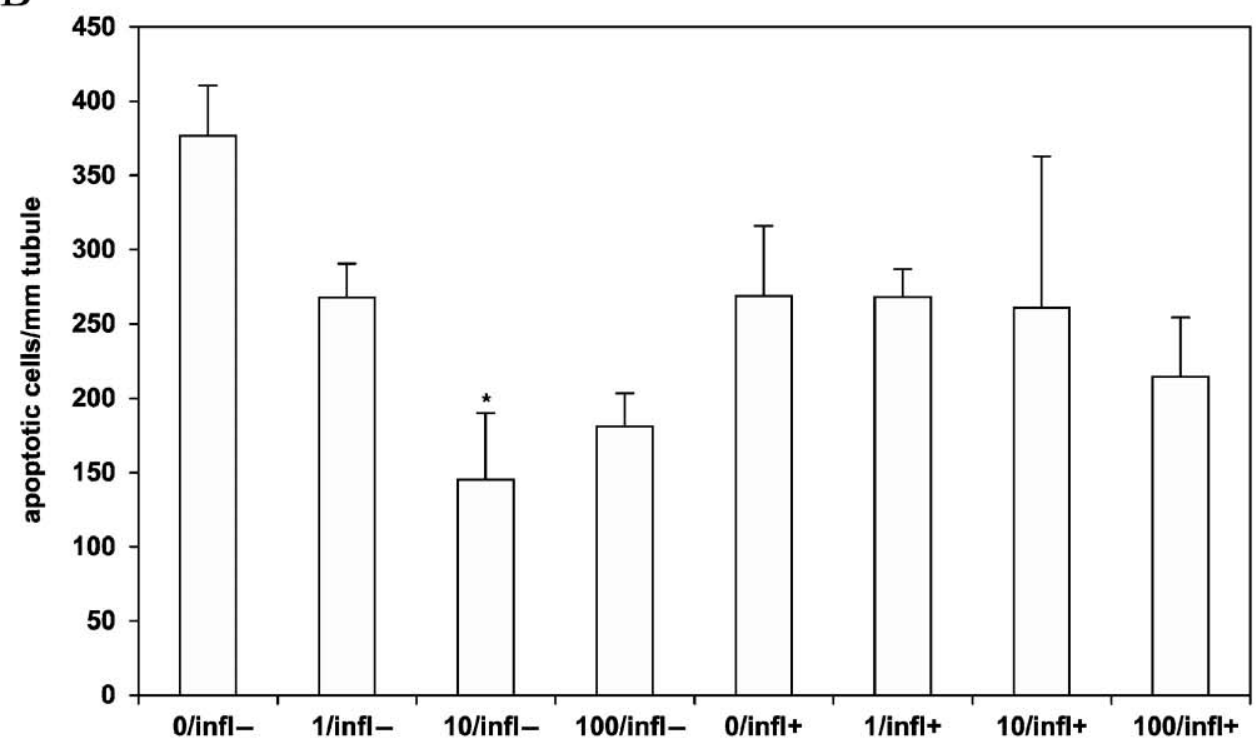

treatment [TNF-alpha concentration $(\mathrm{ng} / \mathrm{ml}) /$ possible infliximab presence marked as -/+]

Figure 1 ISEL staining of the rat seminiferous tubule segments cultured in the presence or absence of different concentrations of TNF- $\alpha$ with and without infliximab. (A) Microphotograph of representative specimens showing the ISEL-positive cells at stage XII of the rat seminiferous epithelial cycle after $24 \mathrm{~h}$ of treatment with vehicle (control), TNF- $\alpha$ ( $10 \mathrm{ng} / \mathrm{ml})$, infliximab or TNF- $\alpha$ (10 $\mathrm{ng} / \mathrm{ml}) \mathrm{plus}$ infliximab. Dark nuclei are apoptotic cells, some of which are marked with white arrows as examples. Black arrows indicate the openings of the lumina of the tubules. Bar, $50 \mu \mathrm{m}$. (B) Quantitative analysis of ISEL staining of three independent experiments with three to four parallel samples using different rats. Each bar represents the number of ISEL-positive cells per $1 \mathrm{~mm}$ of seminiferous tubule as the mean \pm S.E.M., $n=3$. ${ }^{*} P<0.05$ (compared with control). 
A
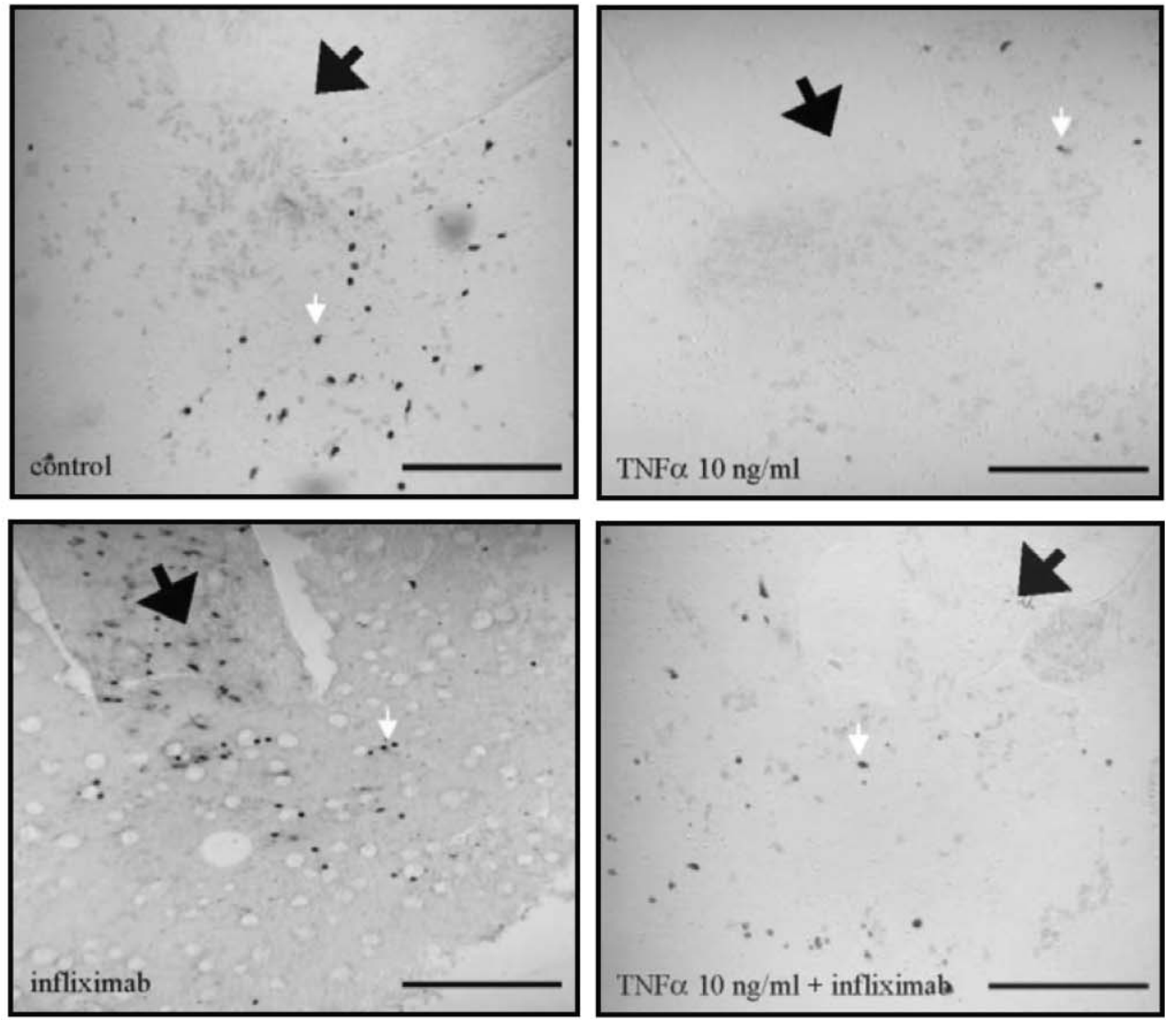

B

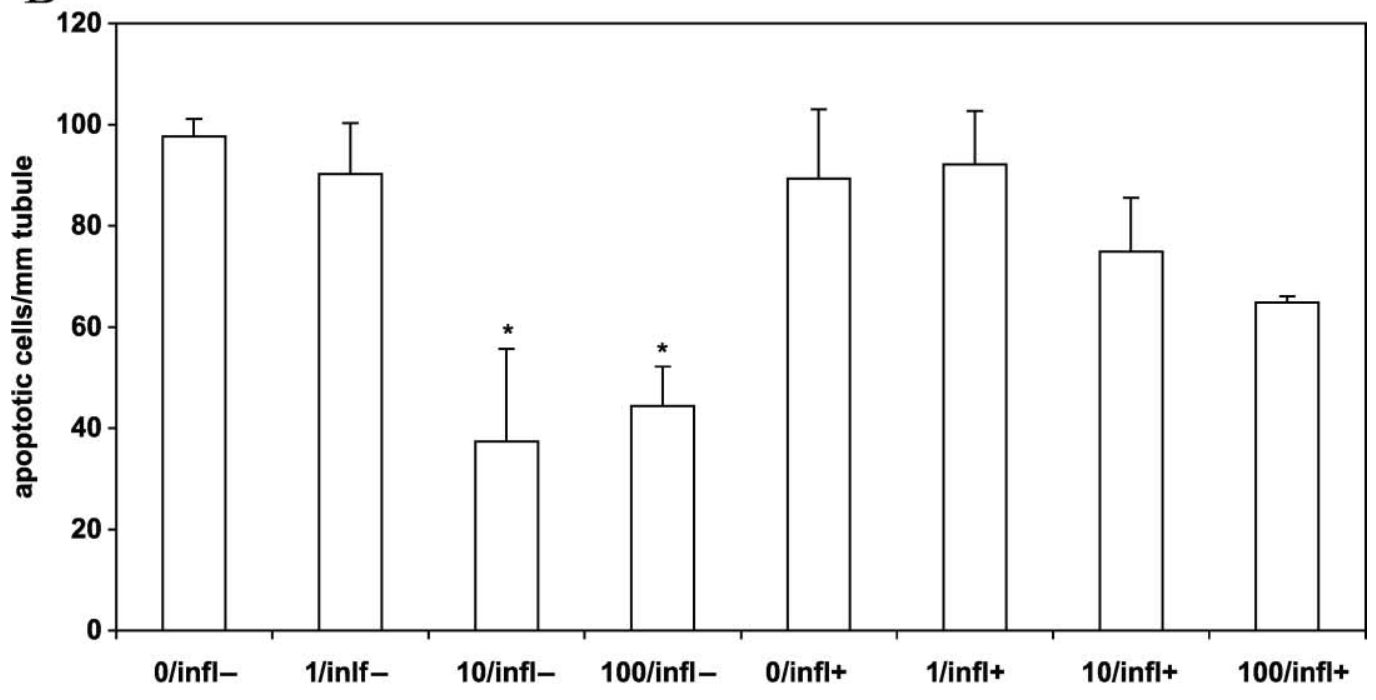

treatment [TNF-alpha concentration $(\mathrm{ng} / \mathrm{ml}) /$ possible infliximab presence marked as $-l+$ ]

Figure 2 Immunohistochemistry with cleaved caspase-3 antibody of seminiferous tubule segments cultured in the presence or absence of different concentrations of TNF- $\alpha$ with and without infliximab. (A) Microphotograph of representative specimens showing the cleaved caspase-3-positive cells at stage XII of the rat seminiferous epithelial cycle after $8 \mathrm{~h}$ of treatment with vehicle (control), TNF- $\alpha$ (10 ng/ml), infliximab or TNF- $\alpha(10 \mathrm{ng} / \mathrm{ml})$ plus infliximab. Dark nuclei are apoptotic cells, some of which are marked with white arrows as examples. Black arrows indicate the openings of the lumina of the tubules. Bar, $50 \mu \mathrm{m}$. (B) Quantitative analysis of cleaved caspase-3 immunohistochemistry of three independent experiments with three to four parallel samples using different rats. Each bar represents the number of cleaved caspase-3-positive cells per 1-mm-long tubule as the mean \pm S.E.M., $n=3 .{ }^{*} P<0.05$ (compared with control). 
A
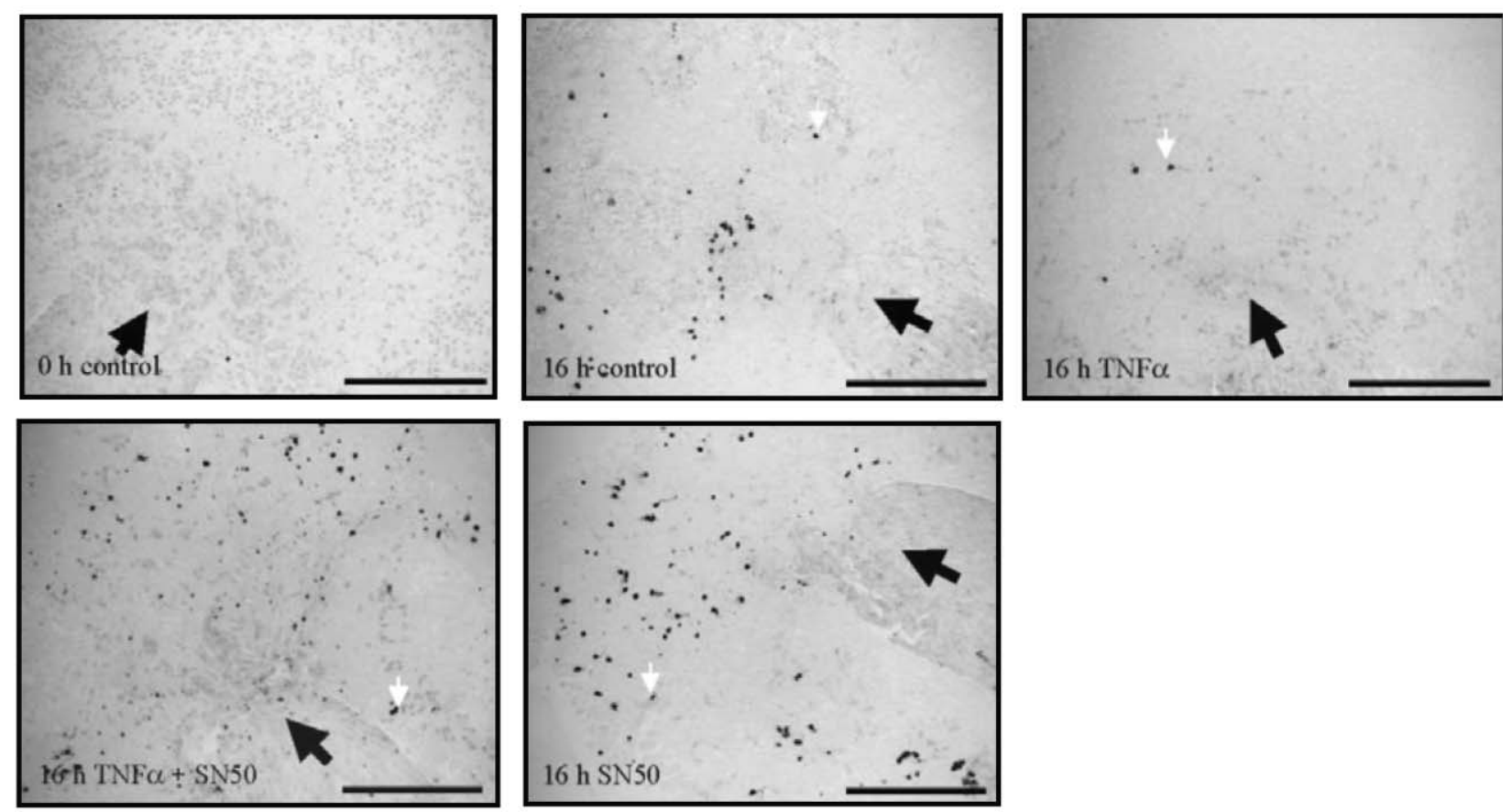

B

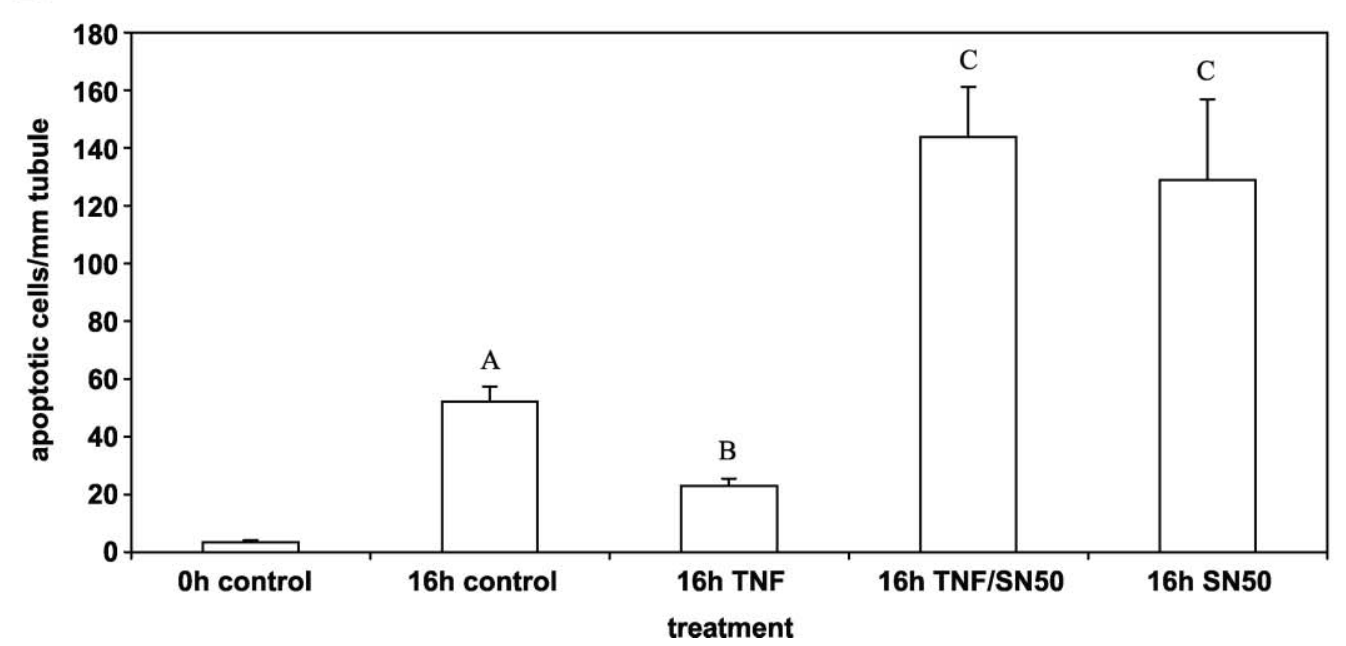

Figure 3 Immunohistochemistry with cleaved caspase-3 antibody for seminiferous tubule segments cultured in the presence or absence of TNF- $\alpha$ with and without SN50, a NF-kB inhibitor. (A) Microphotograph of representative specimens showing the cleaved caspase-3positive cells at stage XII of the rat seminiferous epithelial cycle after $16 \mathrm{~h}$ of treatment with vehicle (control), TNF- $\alpha$ (10 ng/ml), SN50 or TNF- $\alpha$ plus SN50. Dark nuclei are apoptotic cells, some of which are marked with white arrows as examples. Black arrows indicate the openings of the lumina of the tubules. Bar, $50 \mu \mathrm{m}$. (B) Quantitative analysis of cleaved caspase-3 immunohistochemistry of three independent experiments with three to four parallel samples using different rats. Each bar represents the number of cleaved caspase-3positive cells per 1 -mm-long tubule as the mean \pm S.E.M. Bars with different letters are statistically different $(P<0.05, n=3)$.

the cytosolic fraction of Bcl-xL. Bax expression remained unchanged in both cytosolic and mitochondrial fractions during the incubation. Spontaneous cytochrome $\mathrm{c}$ release to cytosol was observed during 6-h incubation. However, TNF- $\alpha$ did not prevent this release significantly.

\section{Discussion}

In the present study, we have shown the cell-survival effect of TNF- $\alpha$ on rat seminiferous epithelium and the blocking of this survival effect by infliximab, a TNF- $\alpha$ antagonist. The two techniques used for 

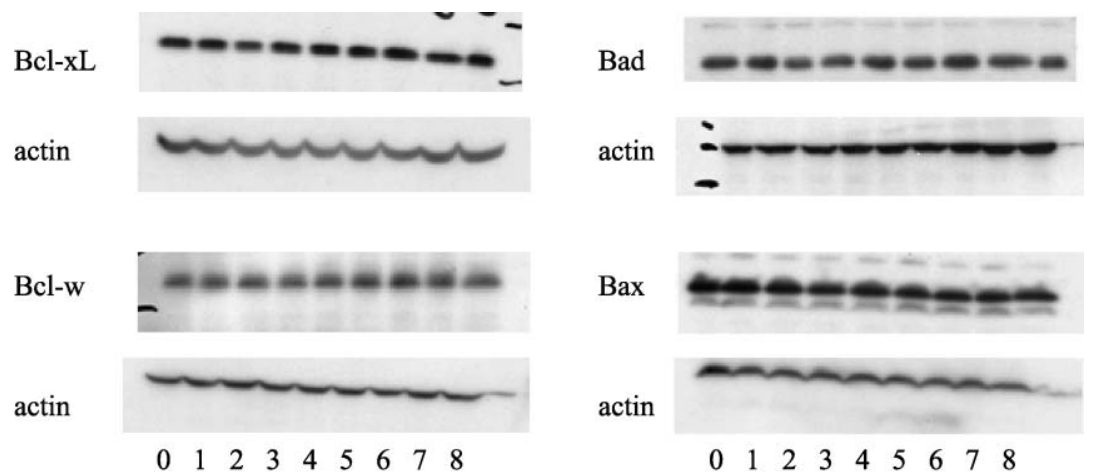

Figure 4 Western blotting images showing the expression of Bcl-xL, Bcl-w, Bad and Bax analyzed in total tubule homogenates from pooled stages IX-XII of the rat seminiferous epithelial cycle. The tubule segments were cultured in the presence or absence of different concentrations of TNF- $\alpha$ with and without infliximab for $21 \mathrm{~h}$. The blots were stripped and subsequently reprobed with an antiactin monoclonal antibody for normalization of loading. The numbers refer to different treatments as follows: (0) 0 h, control; (1-8) 21-h incubation, (1-4) without infliximab and (5-8) with infliximab, (1, 5) control; $(2,6)$ TNF- $\alpha 1 \mathrm{ng} / \mathrm{ml} ;(3,7)$, TNF- $\alpha 10 \mathrm{ng} / \mathrm{ml} ;(4,8)$ TNF- $\alpha 100 \mathrm{ng} / \mathrm{ml}$. The images are representative of three sets of independent experiments using different rats. No significant changes were observed in the expression of Bcl-xL, Bcl-w, Bad and Bax analyzed in total tubule homogenates from pooled stages IX-XII of the rat seminiferous epithelial cycle.

evaluation of apoptosis were in situ $3^{\prime}$-end labeling (ISEL) and cleaved caspase-3 immunohistochemistry. DNA fragmentation is a prominent and late feature in programmed cell death, and apoptotic cells can be identified and quantified with ISEL (21). The main intracellular effectors of apoptosis are a family of cysteine proteases called caspases (22). Caspase-3, a downstream caspase in the caspase cascade, is activated by proteolytic processing. With immunohistochemistry, positive cells for cleaved caspase-3 were easily distinguishable and were identified as germ cells on the basis of staining pattern and morphology. ISEL and immunohistochemistry were applied in combination with squash preparation of isolated seminiferous tubule segments from stage XII of the rat seminiferous epithelial cycle, as stage XII has been shown to be prone to spontaneous apoptosis (23). Both techniques gave similar results, as they clearly showed a cell-survival effect by TNF- $\alpha$ on rat seminiferous epithelium and the blocking of this survival effect by infliximab, which is in therapeutic use for $\mathrm{RA}$ and $\mathrm{CD}(12,13)$. In addition, patients with psoriasis have experienced a clinical benefit from treatment with infliximab (24). Infliximab neutralizes the effect of TNF- $\alpha$, but part of the effect in the treatment of $\mathrm{CD}$ might be mediated by the proapoptotic effect of infliximab on T lymphocytes in the gut mucosa (14). In our study, infliximab did not show any effect on the amount of apoptosis compared with control, but the ability of infliximab to block the prosurvival effect of TNF- $\alpha$ on the seminiferous epithelium might have clinical relevance when patients are receiving anti-inflammatory treatment with infliximab. In the mouse testis, TNF- $\alpha$ is produced in the pachytene spermatocytes and round spermatids, and the receptor TNFR1 has been identified in Sertoli cells (7). The localization of TNFR1 suggests that the effects of TNF- $\alpha$ on germ cells are paracrine rather than direct. TNF- $\alpha$ simultaneously activates both apoptotic and cell-survival signals. The apoptotic signals are mediated through the death domain of TNFR1, leading to the activation of the caspase cascade. These apoptotic signals do not require active protein synthesis, whereas cell-survival effects do. The protein synthesis is mediated through the activation of NF- $\mathrm{KB}$ (25), a transcription factor that regulates a multitude of genes, including many genes that promote cell survival, such as members of the inhibitors of apoptosis (IAP) family (c-IAP1 and c-IAP2) and the Bcl2 family (Bfl-1/A1 and Bcl-xL) (26-29). NF-kB exists in an inactive cytoplasmic complex with an inhibitory protein, IкB. Activation of TNFR 1 leads to degradation of IкB by ІкB kinases and release of the active NF-кB complex, which translocates to the nucleus. We performed an experiment in which this translocation of the active complex was inhibited by SN50 (19). Inactivation of NF- $\kappa$ B abolished the prosurvival effect of TNF- $\alpha$. In fact, massive apoptosis occurred when seminiferous tubules were cultured with SN50, indicating the importance of NF- $\mathrm{kB}$ as a mediator of prosurvival effects.

Proteins of the Bcl-2 family are important mediators of apoptotic signaling (22). The functions of Bcl-2 family proteins are regulated at several levels. Changes in subcellular localization, expression and post-translational modifications (such as phosphorylation and deamidation) of Bcl-2 family proteins tune their functions (30-33). We studied whether TNF- $\alpha$ stimulation has an impact on the expression of certain important Bcl2 family members. We have earlier shown that stem cell factor ( $\mathrm{SCF}$ ) promotes cell survival during spermatogenesis by upregulating the prosurvival Bcl-2 family proteins, Bcl-w and Bcl-xL, and downregulating proapoptotic Bax (23). When they were analyzed in total seminiferous tubule homogenates, no alterations in 
A

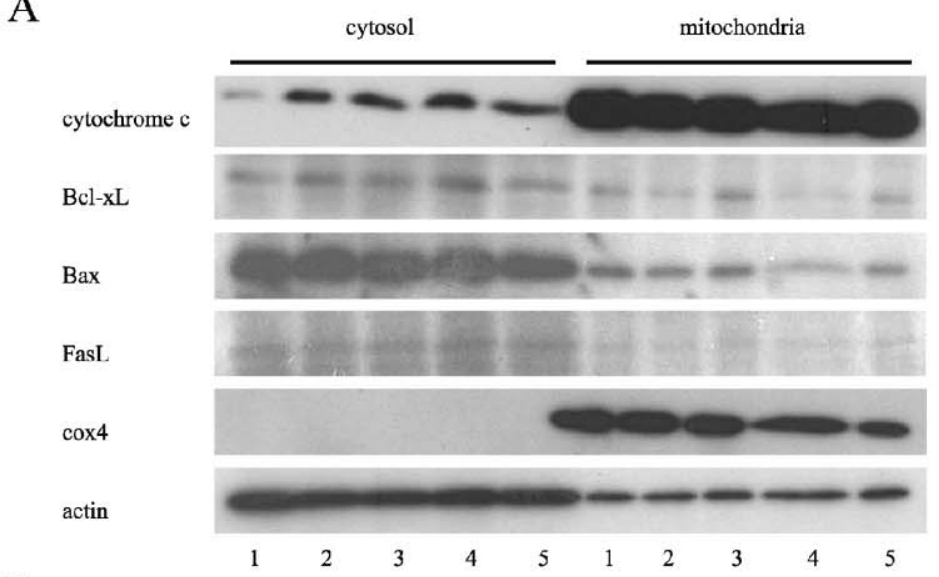

B

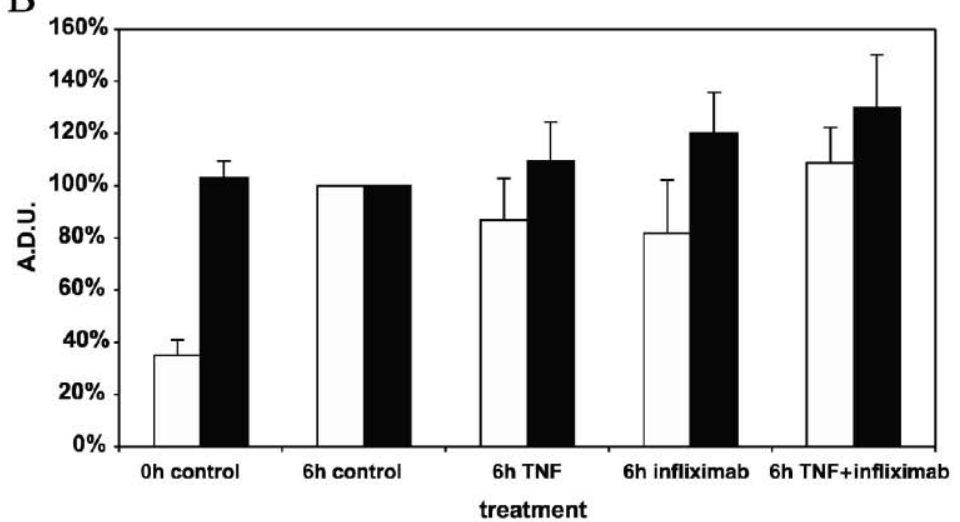

cytochrome $\mathrm{c}$ in cytoso

a fasL in cytosol

C

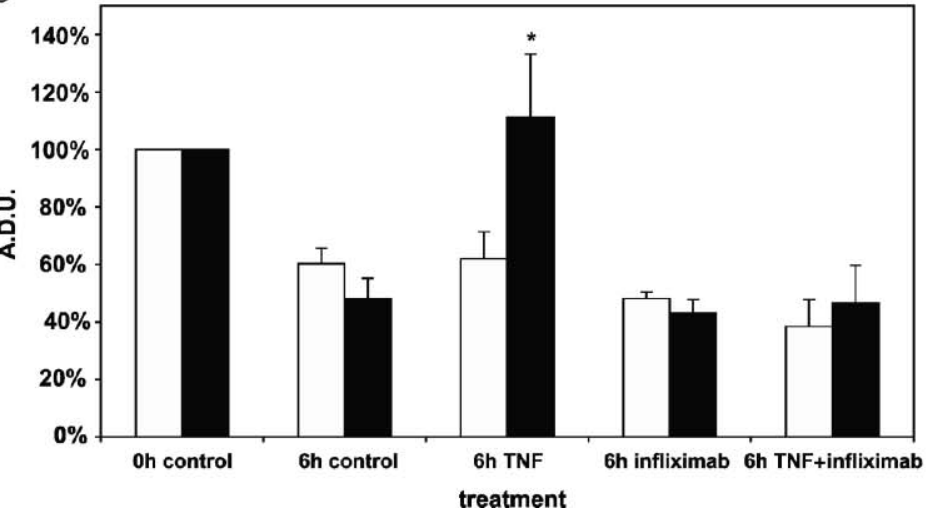

bax in mitochondria

bcl-xl in mitochondria

Figure 5 Western blotting results for cytochrome c, Bcl-xL, Bax and Fas ligand from subcellular fractions. Pooled stages IX-XII of the rat seminiferous epithelial cycle were cultured for $6 \mathrm{~h}$ in the presence or absence of TNF- $\alpha$ with and without infliximab; subsequently, subcellular fractions were extracted for Western blotting analyses. (A) Western blotting images showing the expression of cytochrome $\mathrm{c}, \mathrm{Bcl}-\mathrm{xL}$, Bax and Fas ligand in cytosolic and mitochondrial fractions. The blots were stripped and subsequently reprobed with the next antibody. The numbers refer to different treatments as follows: (1) $0 \mathrm{~h}$, control; (2) $6 \mathrm{~h}$, control; (3) $6 \mathrm{~h}$, TNF- $\alpha(10 \mathrm{ng} / \mathrm{ml}) ;(4) 6 \mathrm{~h}$, infliximab; (5) $6 \mathrm{~h}, \mathrm{TNF}-\alpha(10 \mathrm{ng} / \mathrm{ml})$ plus infliximab. Spontaneous cytochrome c release to cytosol was observed during 6-h incubation. During 6-h incubation, the amount of $\mathrm{Bcl}-\mathrm{xL}$ decreased in the mitochondrial fraction compared with 0-h control. TNF- $\alpha$ stimulation increased the amount of $\mathrm{Bcl}-\mathrm{xL}$ in the mitochondrial fraction. Infliximab blocked this increase. No changes were observed in the cytosolic fraction of $\mathrm{Bcl}-\mathrm{xL}$. Bax expression remained unchanged in both the cytosolic and mitochondrial fractions during the incubation. Monoclonal antiactin antibody was used for normalization of loading, and COX4 antibody was used to verify the purity of the cytosolic fraction, that is, the fraction not containing mitochondria. For cytosolic and mitochondrial samples, 8 and $2 \mu \mathrm{g}$ of protein were loaded respectively. The images are representative of three sets of independent experiments using different rats. (B) Quantitative analysis of the expression of cytochrome $\mathrm{c}$ and fas ligand in cytosol. No significant changes were seen during the 6-h incubation. The 6-h control is designated as $100 \%$. Each bar represents the mean \pm S.E.M. of three independent experiments. A.D.U., arbitrary densitometric units. (C) Quantitative analysis of the expression of Bax and Bcl-xL in mitochondria. The 0-h control is designated as $100 \%$. Each bar represents the mean \pm S.E.M. of three independent experiments. A.D.U., arbitrary densitometric units. ${ }^{*} P<0.05$ (compared with 6 -h control). 
the levels of the Bcl-2 family proteins were found in the presence of TNF- $\alpha$ or infliximab. Since the subcellular localization is an important factor affecting the function of Bcl-2 family members, we studied whether TNF- $\alpha$ and/or infliximab have a regulatory effect on Bax and Bcl-xL at the subcellular level. During 6-h incubation, the amount of Bcl-xL decreased in the mitochondrial fraction, but TNF- $\alpha$ was able to prevent this decrease, as the level of $\mathrm{Bcl}-\mathrm{xL}$ protein was restored in mitochondria at the level of control extracted before the start of the culture. Infliximab was able to abolish this effect of TNF- $\alpha$. Bcl-xL is specifically targeted on the mitochondrial outer membrane (34), but it is also found in cytosol (35), whereas Bax is predominantly a cytosolic protein (35). Bcl-xL is localized to spermatocytes and spermatids in the adult rat testis (36), and Bcl-xL might account for the protective effects of TNF$\alpha$ in these cells, as the apoptotic germ cells were mostly primary spermatocytes and spermatids. The mechanism of the protective effect of Bcl-xL on apoptosis has been studied intensively. Bcl-xL has been shown to prevent Bax-induced cytochrome c release from mitochondria (37). Bcl-xL dimerizes with Bax but also inhibits apoptosis independently of Bax (38-40). Bcl$\mathrm{xL}$ has a structural similarity with pore-forming bacterial toxins, and it forms ion-conducting channels in lipid membranes $(41,42)$. Controversial reports have appeared on its ability to interact with Apaf-1 (43-46). In the presence of dATP and cytochrome c, Apaf-1 binds to caspase-9, leading to the activation of caspase-3 (47). The ability of Bcl-xL to inhibit apoptosis cannot be due solely to the inhibition of cytochrome $c$ release from mitochondria, since a microinjection of cytochrome $\mathrm{c}$ in cytochrome c-insensitive MCF7F cells does not overcome the antiapoptotic effects of Bcl-xL (48). In our study, no changes were seen in the expression of Bcl-xL in the cytoplasm, and as Apaf-1 is a cytosolic protein, it is more probable that antiapoptotic Bcl-xL action takes place in mitochondria. However, localization of Bcl-xL to the outer mitochondrial membrane might still enable Bcl-xL to interact with Apaf-1. No changes were seen in the expression of Bax during 6-h culture in either the mitochondria or cytosol. Bax protein has a long half-life, possibly explaining the absence of TNF- $\alpha$ effect during a short culture period (49). TNF- $\alpha$ has been shown to induce Bcl-xL expression through NF- $\mathrm{B}$ activation in neuronal cells (50). Bax forms a dimer with Bcl-xL, preventing the death-repressor activity of this antiapoptotic protein (39). This might be one pathway of cell survival in the seminiferous epithelium, since Bcl-xL was clearly upregulated in mitochondria without any effect on Bax expression. The effect was not mediated through the release of cytochrome c, as no decrease was observed in the cytosolic cytochrome c content in the presence of TNF- $\alpha$. There are several other apoptogenic factors besides the cytochrome c released from mitochondria, such as HtrA2/Omi, endonuclease G, Smac/DIABLO and AIF, which might serve as targets of the prosurvival effect of TNF- $\alpha$. Besides controlling the release of apoptogenic factors from intermembrane space, Bcl-xL can act on the voltage-dependent anion channel (VDAC) maintaining free metabolite exchange across the outer mitochondrial membrane during cellular stress (51). Spermatogenesis is highly dependent on hormonal regulation, and survival of germ cells is regulated by different hormones, growth factors and cytokines (52). We have earlier shown that follicle-stimulating hormone (FSH) protects germ cells from apoptosis, and this effect is mediated partially through the SCF/c-kit pathway $(53,54)$ and may at least partly be due to the inhibition of proapoptotic Bok gene expression (55). Furthermore, TNFR1 expression in Sertoli cells is increased by FSH (8), and TNF- $\alpha$ has been shown to inhibit FSH action on cultured Sertoli cells (56). TNF- $\alpha$ has been shown to inhibit apoptosis in human seminiferous tubules by a mechanism that did not appear to be associated with the NF- $\mathrm{B}$ pathway (10). TNF- $\alpha$ modulated the Fas system by downregulating the expression of Fas ligand. In our study, Fas ligand expression was not affected by TNF- $\alpha$, suggesting that the mechanism of action for promoting cell survival is different between rat and human seminiferous epithelium. All in all, we have shown that TNF- $\alpha$ promotes cell survival during spermatogenesis, and this effect can be blocked by infliximab. This finding is important, as infliximab is in therapeutic use for autoimmune disorders such as RA and CD. The prosurvival effect of TNF- $\alpha$ might be at least partly mediated by modulating the expression and subcellular localization of Bcl-2 family proteins, as Bcl-xL was found to be upregulated in mitochondrial membranes in the presence of TNF- $\alpha$, and this upregulation was inhibited by infliximab. Further studies are needed to understand the exact mechanism of action of TNF- $\alpha$ on cell survival in the testis and to evaluate the present findings in terms of the clinical use of infliximab.

\section{Acknowledgements}

This work was supported by grants from the EU Quality of Life and Management of Living Resources Program, the Academy of Finland, Turku University Central Hospital, the Finnish University Society, the Emil and Blida Maunula Foundation of the University of Turku, the Finnish Medical Foundation and the Finnish Cultural Foundation.

\section{References}

1 Oakberg EF. A description of spermiogenesis in the mouse and its use in analysis of the cycle of the seminiferous epithelium and germ cell renewal. American Journal of Anatomy 195699 391-413.

2 Allan DJ, Harmon BV \& Roberts SA. Spermatogonial apoptosis has three morphologically recognizable phases and shows no 
circadian rhythm during normal spermatogenesis in the rat. Cell Proliferation 199225 241-250.

3 Russell LD \& Peterson RN. Determination of the elongate spermatidSertoli cell ratio in various mammals. Journal of Reproduction and Fertility 198470 635-641.

4 Aggarwal BB, Kohr WJ, Hass PE, Moffat B, Spencer SA, Henzel WJ, Bringman TS, Nedwin GE, Goeddel DV \& Harkins RN. Human tumor necrosis factor. Production, purification, and characterization. Journal of Biological Chemistry $19852602345-2354$.

5 Pennica D, Nedwin GE, Hayflick JS, Seeburg PH, Derynck R, Palladino MA, Kohr WJ, Aggarwal BB \& Goeddel DV. Human tumour necrosis factor: precursor structure, expression and homology to lymphotoxin. Nature $1984312724-729$.

6 Baker SJ \& Reddy EP. Modulation of life and death by the TNF receptor superfamily. Oncogene $1998173261-3270$.

7 De SK, Chen HL, Pace JL, Hunt JS, Terranova PF \& Enders GC. Expression of tumor necrosis factor-alpha in mouse spermatogenic cells. Endocrinology 1993133 389-396.

8 Mauduit C, Besset V, Caussanel V \& Benahmed M. Tumor necrosis factor alpha receptor p55 is under hormonal (follicle-stimulating hormone) control in testicular Sertoli cells. Biochemical and Biophysical Research Communications 1996224 631-637.

9 Mauduit C, Gasnier F, Rey C, Chauvin MA, Stocco DM, Louisot P \& Benahmed M. Tumor necrosis factor-alpha inhibits Leydig cell steroidogenesis through a decrease in steroidogenic acute regulatory protein expression. Endocrinology $19981392863-2868$.

10 Pentikainen V, Erkkila K, Suomalainen L, Otala M, Pentikainen MO, Parvinen M \& Dunkel L. TNFalpha down-regulates the Fas ligand and inhibits germ cell apoptosis in the human testis. Journal of Clinical Endocrinology and Metabolism 200186 4480-4488.

11 Knight DM, Trinh H, Le J, Siegel S, Shealy D, McDonough M, Scallon B, Moore MA, Vilcek J, Daddona P \& Ghrayeb J. Construction and initial characterization of a mouse-human chimeric antiTNF antibody. Molecular Immunology $1993301443-1453$.

12 Lipsky PE, van der Heijde DM, St Clair EW, Furst DE, Breedveld FC, Kalden JR, Smolen JS, Weisman M, Emery P, Feldmann M, Harriman GR \& Maini RN. Infliximab and methotrexate in the treatment of rheumatoid arthritis. Anti-Tumor Necrosis Factor Trial in Rheumatoid Arthritis with Concomitant Therapy Study Group. New England Journal of Medicine 2000343 1594-1602.

13 Targan SR, Hanauer SB, van Deventer SJ, Mayer L, Present DH, Braakman T, DeWoody KL, Schaible TF \& Rutgeerts PJ. A shortterm study of chimeric monoclonal antibody cA2 to tumor necrosis factor alpha for Crohn's disease. Crohn's Disease cA2 Study Group. New England Journal of Medicine 1997337 1029-1035.

14 ten Hove T, van Montfrans C, Peppelenbosch MP \& van Deventer SJ. Infliximab treatment induces apoptosis of lamina propria T lymphocytes in Crohn's disease. Gut 200250 206-211.

15 Cory S \& Adams JM. The Bcl2 family: regulators of the cellular life-or-death switch. Nature Reviews Cancer 20022 647-656.

16 Parvinen M \& Vanha-Perttula T. Identification and enzyme quantitation of the stages of the seminiferous epithelial wave in the rat. Anatomical Record $1972 \mathbf{1 7 4} 435-449$.

17 Toppari J \& Parvinen M. In vitro differentiation of rat seminiferous tubular segments from defined stages of the epithelial cycle: morphologic and immunolocalization analysis. Journal of Andrology $19856334-343$.

18 Scallon B, Cai A, Solowski N, Rosenberg A, Song XY, Shealy D \& Wagner C. Binding and functional comparisons of two types of tumor necrosis factor antagonists. Journal of Pharmacology and Experimental Therapeutics $2002301418-426$.

19 Lin YZ, Yao SY, Veach RA, Torgerson TR \& Hawiger J. Inhibition of nuclear translocation of transcription factor NF-kappa B by a synthetic peptide containing a cell membrane-permeable motif and nuclear localization sequence. Journal of Biological Chemistry $199527014255-14258$.

20 Billig H, Furuta I \& Hsueh AJ. Estrogens inhibit and androgens enhance ovarian granulosa cell apoptosis. Endocrinology 1993 $1332204-2212$.
21 Henriksen K, Hakovirta H \& Parvinen M. In-situ quantification of stage-specific apoptosis in the rat seminiferous epithelium: effects of short-term experimental cryptorchidism. International Journal of Andrology 199518 256-262.

22 Hengartner MO. The biochemistry of apoptosis. Nature $2000 \mathbf{4 0 7}$ $770-776$.

23 Yan W, Suominen J, Samson M, Jegou B \& Toppari J. Involvement of Bcl-2 family proteins in germ cell apoptosis during testicular development in the rat and pro-survival effect of stem cell factor on germ cells in vitro. Molecular and Cellular Endocrinology 2000 $165115-129$.

24 Chaudhari U, Romano P, Mulcahy LD, Dooley LT, Baker DG \& Gottlieb AB. Efficacy and safety of infliximab monotherapy for plaque-type psoriasis: a randomised trial. Lancet 2001357 $1842-1847$

25 Karin M \& Lin A. NF-kappaB at the crossroads of life and death. Nature Immunology $20023221-227$.

26 Wang CY, Mayo MW, Korneluk RG, Goeddel DV \& Baldwin AS Jr. NFkappaB antiapoptosis: induction of TRAF1 and TRAF2 and c-IAP1 and cIAP2 to suppress caspase- 8 activation. Science 1998281 1680-1683.

27 Zong WX, Edelstein LC, Chen C, Bash J \& Gelinas C. The prosurvival Bcl-2 homolog Bfl-1/A1 is a direct transcriptional target of NF-kappaB that blocks TNFalpha-induced apoptosis. Genes and Development 199913 382-387.

28 Ravi R, Bedi GC, Engstrom LW, Zeng Q, Mookerjee B, Gelinas C, Fuchs EJ \& Bedi A. Regulation of death receptor expression and TRAIL/Apo2L-induced apoptosis by NF-kappaB. Nature Cell Biology 20013 409-416.

29 Chen C, Edelstein LC \& Gelinas C. The Rel/NF-kappaB family directly activates expression of the apoptosis inhibitor $\mathrm{Bcl}-\mathrm{x}(\mathrm{L})$. Molecular and Cellular Biology $2000202687-2695$.

30 Zha H, Fisk HA, Yaffe MP, Mahajan N, Herman B \& Reed JC. Structure-function comparisons of the proapoptotic protein Bax in yeast and mammalian cells. Molecular and Cellular Biology $1996166494-6508$

31 Deverman BE, Cook BL, Manson SR, Niederhoff RA, Langer EM, Rosova I, Kulans LA, Fu X, Weinberg JS, Heinecke JW, Roth KA $\&$ Weintraub SJ. BclxL deamidation is a critical switch in the regulation of the response to DNA damage. Cell $200211151-62$.

32 Putcha GV, Le S, Frank S, Besirli CG, Clark K, Chu B, Alix S, Youle RJ, LaMarche A, Maroney AC \& Johnson EM Jr. JNKmediated BIM phosphorylation potentiates BAX-dependent apoptosis. Neuron $2003 \mathbf{3 8} 899-914$.

33 Breitschopf K, Haendeler J, Malchow P, Zeiher AM \& Dimmeler S. Posttranslational modification of $\mathrm{Bcl}-2$ facilitates its proteasomedependent degradation: molecular characterization of the involved signaling pathway. Molecular and Cellular Biology 2000 20 1886-1896.

34 Kaufmann T, Schlipf S, Sanz J, Neubert K, Stein R \& Borner C. Characterization of the signal that directs $\mathrm{Bcl}-\mathrm{x}(\mathrm{L})$, but not Bcl-2, to the mitochondrial outer membrane. Journal of Cell Biology $200316053-64$.

35 Hsu YT, Wolter KG \& Youle RJ. Cytosol-to-membrane redistribution of Bax and Bcl-X(L) during apoptosis. PNAS 199794 3668-3672.

36 Krajewski S, Krajewska M, Shabaik A, Wang HG, Irie S, Fong L \& Reed JC. Immunohistochemical analysis of in vivo patterns of Bcl-X expression. Cancer Research 199454 5501-5507.

37 Finucane DM, Bossy-Wetzel E, Waterhouse NJ, Cotter TG \& Green DR. Bax-induced caspase activation and apoptosis via cytochrome $\mathrm{c}$ release from mitochondria is inhibitable by Bcl-xL. Journal of Biological Chemistry $19992742225-2233$.

38 Cheng EH, Levine B, Boise LH, Thompson CB \& Hardwick JM. Bax-independent inhibition of apoptosis by Bcl-XL. Nature 1996 $379554-556$.

39 Sato $\mathrm{T}$, Hanada $\mathrm{M}$, Bodrug $\mathrm{S}$, Irie $\mathrm{S}$, Iwama $\mathrm{N}$, Boise $\mathrm{LH}$, Thompson CB, Golemis E, Fong L \& Wang HG. Interactions among members of the Bcl-2 protein family analyzed with a yeast two-hybrid system. PNAS $1994919238-9242$. 
40 Sedlak TW, Oltvai ZN, Yang E, Wang K, Boise LH, Thompson CB \& Korsmeyer SJ. Multiple Bcl-2 family members demonstrate selective dimerizations with Bax. PNAS 199592 7834-7838.

41 Minn AJ, Velez P, Schendel SL, Liang H, Muchmore SW, Fesik SW, Fill M \& Thompson CB. Bcl-x(L) forms an ion channel in synthetic lipid membranes. Nature $1997385353-357$.

42 Muchmore SW, Sattler M, Liang H, Meadows RP, Harlan JE, Yoon HS, Nettesheim D, Chang BS, Thompson CB, Wong SL, Ng SL \& Fesik SW. X-ray and NMR structure of human Bcl-xL, an inhibitor of programmed cell death. Nature 1996381 335-341.

$43 \mathrm{Hu}$ Y, Benedict MA, Wu D, Inohara N \& Nunez G. Bcl-XL interacts with Apaf-1 and inhibits Apaf-1-dependent caspase-9 activation. PNAS 199895 4386-4391.

44 Moriishi K, Huang DC, Cory S \& Adams JM. Bcl-2 family members do not inhibit apoptosis by binding the caspase activator Apaf-1. PNAS 199996 9683-9688.

45 Hausmann G, O'Reilly LA, van Driel R, Beaumont JG, Strasser A, Adams JM \& Huang DC. Pro-apoptotic apoptosis protease-activating factor 1 (Apaf-1) has a cytoplasmic localization distinct from Bcl-2 or Bcl-x(L). Journal of Cell Biology $2000149623-634$.

46 Yajima $\mathrm{H}$ \& Suzuki F. Identification of a Bcl-XL binding region within the ATPase domain of Apaf-1. Biochemical and Biophysical Research Communications 2003309 520-527.

47 Li P, Nijhawan D, Budihardjo I, Srinivasula SM, Ahmad M, Alnemri ES \& Wang X. Cytochrome c and dATP-dependent formation of Apaf-1/caspase-9 complex initiates an apoptotic protease cascade. Cell $199791479-489$.

48 Li F, Srinivasan A, Wang Y, Armstrong RC, Tomaselli KJ \& Fritz LC. Cell-specific induction of apoptosis by microinjection of cytochrome c. Bcl-xL has activity independent of cytochrome c release. Journal of Biological Chemistry 1997272 30299-30305.

49 Bentires-Alj M, Dejardin E, Viatour P, Van Lint C, Froesch B, Reed JC, Merville MP \& Bours V. Inhibition of the NF-kappa B transcription factor increases Bax expression in cancer cell lines. Oncogene $2001202805-2813$.
50 Tamatani M, Che YH, Matsuzaki H, Ogawa S, Okado H, Miyake S, Mizuno T \& Tohyama M. Tumor necrosis factor induces Bcl-2 and Bcl-x expression through NFkappaB activation in primary hippocampal neurons. Journal of Biological Chemistry $1999 \mathbf{2 7 4}$ $8531-8538$.

51 Vander Heiden MG, Li XX, Gottleib E, Hill RB, Thompson CB \& Colombini M. Bcl-xL promotes the open configuration of the voltage-dependent anion channel and metabolite passage through the outer mitochondrial membrane. Journal of Biological Chemistry 2001276 19414-19419.

52 Devouassoux-Shisheboran M, Mauduit C, Tabone E, Droz JP \& Benahmed M. Growth regulatory factors and signalling proteins in testicular germ cell tumours. APMIS $2003111212-224$; discussion 224 .

53 Henriksen K, Kangasniemi M, Parvinen M, Kaipia A \& Hakovirta H. In vitro, follicle-stimulating hormone prevents apoptosis and stimulates deoxyribonucleic acid synthesis in the rat seminiferous epithelium in a stage-specific fashion. Endocrinology $1996 \mathbf{1 3 7}$ 2141-2149.

54 Yan W, Suominen J \& Toppari J. Stem cell factor protects germ cells from apoptosis in vitro. Journal of Cell Science 2000113 $161-168$.

55 Suominen JS, Yan W, Toppari J \& Kaipia A. The expression and regulation of Bcl-2-related ovarian killer (Bok) mRNA in the developing and adult rat testis. European Journal of Endocrinology $2001145771-778$.

56 Mauduit C, Jaspar JM, Poncelet E, Charlet C, Revol A, Franchimont P \& Benahmed M. Tumor necrosis factor-alpha antagonizes follicle-stimulating hormone action in cultured Sertoli cells. Endocrinology 1993133 69-76.

Received 6 July 2004

Accepted 18 August 2004 